\title{
Analisis kemampuan kognitif matematika berdasarkan task commitment siswa kelas khusus olahraga sekolah menengah atas
}

\author{
Nurafni Retno Kurniasih ${ }^{1}$, Idris Harta ${ }^{2}$ \\ ${ }^{1}$ Program Studi Pendidikan Matematika, Program Pascasarjana, Universitas Negeri Yogyakarta. \\ Jalan Colombo No. 1, Karangmalang, Yogyakarta 55281, Indonesia. \\ 2 Program Studi Pendidikan Matematika, Universitas Muhammadiyah Surakarta. \\ Jalan A. Yani, Pabelan, Kartasura, Sukoharjo, Jawa Tengah 57162, Indonesia. \\ ${ }^{1}$ retnoafnii@gmail.com \\ * Corresponding Author
}

\section{ARTICLE INFO}

\section{Article history}

Received: 8 Jan. 2019;

Revised: 24 March 2019;

Accepted: 26 May 2019

\section{Keywords}

kemampuan kognitif matematika; task commitment; siswa kelas khusus olahraga; athlete students; mathematical cognitive abilities; task commitment

\begin{abstract}
Tujuan dari penelitian ini adalah untuk mendeskripsikan kemampuan kognitif matematika, task commitment, dan hubungan antara kemampuan kognitif matematika dan task commitment siswa Kelas Khusus Olahraga (KKO) SMA negeri se-Daerah Istimewa Yogyakarta (DIY). Penelitian ini menggunakan metode survei. Populasi pada penelitian ini yaitu siswa KKO kelas X SMA negeri se-DIY yang berjumlah 319 siswa. Sampel sejumlah 132 siswa yang terbagi dalam 8 sekolah penyelenggara kelas KKO se-DIY ditentukan dengan teknik sampel acak proporsional sistematik. Hasil penelitian ini menunjukkan bahwa kemampuan kognitif matematika siswa KKO SMA negeri se-DIY dalam kategori sedang dengan nilai rata-rata 40,62 dari nilai tertinggi ideal 100, task commitment siswa KKO SMA negeri se-DIY dalam kategori sedang dengan nilai rata-rata 95,63 dari nilai tertinggi ideal 150, dan terdapat hubungan yang cukup kuat antara kemampuan kognitif matematika dan task commitment siswa KKO SMA negeri se-DIY. Hal ini dibuktikan dari nilai koefisien kontingensi $\mathrm{C}_{s}=0,328$ yang berada pada interval $0,30-0,59$ dan nilai signifikansi sebesar 0,05 .
\end{abstract}

The purpose of this study was to describe the mathematical cognitive abilities, the task commitment, and the relationship between mathematical cognitive abilities and task commitment of athlete students in Special Region of Yogyakarta Province, Indonesia. This study was survey research. The population of this study was 319 grade X athlete students of senior high school. A sample of 132 students were established using the systematical proportional random sampling technique. The results of this study showed that the mathematical cognitive abilities of athlete students in Special Region of Yogyakarta was in the medium category with the mean score 40.62 from the ideal score of 100, the task commitment of athlete students in Special Region of Yogyakarta was in the medium category with the mean score 95.63 from the ideal value 150, and there was a moderate association between mathematical cognitive abilities and task commitment of athlete students in Special Region of Yogyakarta. It could be seen by the value of contingency coefficient $\mathrm{C}_{s}=0.328$ which was in interval 0.30 to 0.59 and a significance value of 0.05 .

This is an open access article under the CC-BY-SA license.

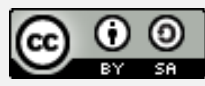

How to Cite: Kurniasih, N., \& Harta, I. (2019). Analisis kemampuan kognitif matematika berdasarkan task commitment siswa kelas khusus olahraga sekolah menengah atas. Jurnal Riset Pendidikan Matematika, 6(1), 1426. doi:https://doi.org/10.21831/jrpm.v6i1.23519 


\section{PENDAHULUAN}

Matematika dipelajari di sekolah dengan memperhatikan perkembangan dan kemampuan kognitif siswa. Mengembangkan kemampuan kognitif atau dapat disebut sebagai kemampuan berpikir merupakan salah satu tujuan pembelajaran matematika. Hal ini sejalan dengan tujuan pembelajaran matematika yang dikemukakan Mahmudi (2016, p. 4) bahwa secara umum tujuan pembelajaran matematika berfokus pada pengembangan kemampuan berpikir, penumbuhan karakter dan perilaku positif. Sejalan dengan pendapat tersebut, Peraturan Menteri Pendidikan dan Kebudayaan Republik Indonesia nomor 24 tahun 2016 tentang Kompetensi Inti (KI) dan Kompetensi Dasar (KD) mendeskripsikan tujuan pembelajaran matematika dalam kompetensi pengetahuan yang harus dicapai siswa dalam KI pelajaran matematika sekolah menengah atas (SMA) yaitu, memahami, menerapkan, dan menganalisis pengetahuan faktual, konseptual dan prosedural. Kompetensi pengetahuan tersebut termasuk kategori dimensi proses kognitif (Anderson et al., 2001, p. 30). Siswa yang memiliki kemampuan kognitif dapat mengaktifkan dan memanfaatkan pengetahuan matematisnya secara efektif untuk memecahkan masalah kontekstual (Turner, 2010, pp. 60-61). Dengan demikian, siswa yang memiliki kemampuan kognitif tinggi akan mudah menerima materi pembelajaran yang disampaikan guru. Selain itu, kemampuan kognitif termasuk di dalamnya pengetahuan matematika, dapat mempengaruhi prestasi matematika (Taub, Floyd, Keith, \& McGrew, 2008, p. 196) dan berkorelasi terhadap kemampuan pemecahan masalah (Bahar, 2013, p. 11). Oleh karena itu, kemampuan kognitif merupakan salah satu kemampuan yang harus dimiliki siswa dalam pembelajaran matematika di sekolah. Kemampuan kognitif harus diberi perhatian lebih pada pembelajaran matematika melalui kegiatan pembelajaran dan melalui penilaian (Turner, 2010, p. 61). Tinggi rendahnya kemampuan kognitif matematika siswa dapat diketahui berdasarkan analisis skor hasil pengukuran kemampuan tersebut.

Evaluasi kemampuan kognitif siswa ditunjukkan pada hasil Ujian Nasional (UN). Hasil UN Matematika SMA Negeri di Daerah Istimewa Yogyakarta (DIY) program studi IPS selama empat tahun terakhir tersaji dalam Tabel 1.

Tabel 1. Hasil UN Matematika SMA Negeri di DIY

\begin{tabular}{ccccc}
\hline \multirow{2}{*}{ Tahun } & \multicolumn{3}{c}{ Nilai Ujian } & \multirow{2}{*}{ Kriteria } \\
\cline { 2 - 4 } & Rata-Rata & Terendah & Tertinggi & B \\
$2012-2013$ & 6,64 & 2,50 & 10,0 & $\mathrm{C}$ \\
$2013-2014$ & 5,80 & 1,00 & 10,0 & $\mathrm{C}$ \\
$2015-2015$ & 59,72 & 7,50 & 100 & $\mathrm{D}$ \\
$2016-2016$ & 53,84 & 7,50 & 100 & 100 \\
\hline
\end{tabular}

Berdasarkan data pada Tabel 1, dapat dilihat bahwa hasil UN matematika SMA negeri di DIY pada program studi IPS selama lima tahun terakhir mengalami penurunan dan belum mencapai kategori baik. Dengan kata lain, dapat diindikasikan bahwa kemampuan kognitif matematika siswa masih rendah. Adapun SMA negeri penyelenggara kelas KKO (Kelas Khusus Olahraga) di DIY mengelompokkan kelas KKO ke program IPS, sehingga data tersebut dapat pula merepresentasikan keadaan siswa KKO SMA negeri di DIY. Selanjutnya, hasil studi terhadap siswa atlet di SMP/SMA Sekolah Khusus Olahragawan Ragunan Jakarta menunjukkan bahwa kemampuan kognitif siswa atlet yang diukur dari nilai UN menunjukkan kategori cukup, sementara hasil penilaian angket menunjukkan sebanyak 52,89\% siswa berpendapat bahwa tujuan belajar di sekolah kurang tercapai (Hanif, 2011).

DIY merupakan salah satu provinsi di Indonesia yang menyediakan KKO, yaitu kelas khusus bagi siswa yang memiliki bakat di bidang olahraga. Siswa KKO bertanggung jawab mengikuti kegiatan pembelajaran sekaligus wajib melakukan latihan fisik sesuai jadwal dan cabang olahraga yang diminatinya setiap hari, sehingga beban yang ditanggung siswa KKO lebih berat yaitu sebagai atlet dan pelajar. Oleh sebab itu, siswa KKO seringkali mengesampingkan pembelajaran di kelas sehingga prestasi akademiknya belum optimal. Selain itu, persepsi guru terhadap siswa KKO dalam mengikuti pembelajaran masih rendah (Widanarti, 2016).

Sebagai atlet sekaligus pelajar, siswa KKO wajib memiliki komitmen yang kuat dalam menjalankan tugas-tugasnya. Komitmen terhadap tugas dalam dunia psikologi dikenal dengan istilah task commitment. Siswa yang memiliki task commitment tinggi akan terdorong untuk tekun dan ulet 
mengerjakan tugasnya meskipun mengalami berbagai macam rintangan atau hambatan, serta mampu menyelesaikan tugas yang menjadi tanggung jawabnya karena siswa tersebut telah mengikatkan diri terhadap tugas atas kehendaknya sendiri sebagai bentuk motivasi internal (Munandar, 1992, pp. 25-26). Dengan kata lain, siswa yang memiliki task commitment tinggi berpotensi untuk memiliki kemampuan kognitif yang baik sehingga prestasi optimal mereka dapat dicapai. Hal ini diperkuat (Tayibu, 2016, p. 133) bahwa siswa yang tidak memiliki task commitment memiliki hasil belajar rendah meskipun sebenarnya siswa tersebut berpotensi memiliki hasil belajar yang baik. Namun, guru jarang menguji kemampuan afektif siswa, padahal kemampuan afektif penting untuk membantu kemampuan kognitif siswa secara langsung untuk meningkatkan hasil belajar matematika (Veloo, Ali, \& Krishnasamy, 2014, p. 619). Urhahne (2011, p. 229) mengatakan, guru hanya akurat dalam menyimpulkan kinerja siswa namun tidak dapat mengukur kreativitas dan task commitment siswa dengan benar. Selain itu, siswa atlet dan pelatihnya sering mengalami kebingungan untuk mengelola tanggung jawab akademik dan atletik mereka. Siswa atlet juga sering dianggap beresiko karena kendala waktu dan tanggung jawab yang mereka hadapi dalam mengelola karier atletik dan akademik (McGee, 2017, p. 126).

Berdasarkan pemaparan tersebut dapat diasumsikan bahwa dengan task commitment yang tinggi pada pembelajaran matematika, siswa KKO akan cenderung memiliki kemampuan kognitif matematika yang tinggi. Adapun berbagai penelitian yang telah dilakukan sebelumnya terkait task commitment, kemampuan kognitif matematika siswa dan kelas KKO masih dilakukan secara terpisah dan belum spesifik membahas keterkaitan antar variabel tersebut. Terbatasnya informasi tentang kemampuan kognitif matematika dan task commitment yang dilakukan pada siswa KKO di SMA negeri se-DIY menjadikan peneliti tertarik untuk melakukan penelitian yang berkaitan dengan kedua variabel tersebut. Diharapkan penelitian ini dapat memberikan informasi tentang kemampuan kognitif matematika dan task commitment siswa KKO sehingga dapat dijadikan bahan pertimbangan dan referensi untuk melakukan perbaikan, meningkatkan dan mengembangkan potensi siswa KKO di DIY dan di seluruh Indonesia. Adapun tujuan dari penelitian ini yaitu untuk mendeskripsikan kemampuan kognitif matematika yang meliputi aspek pengetahuan, penerapan dan penalaran, task commitment yang meliputi aspek ketekunan, ketahanan, percaya diri, dedikasi pada latihan, dan minat, serta mendeskripsikan hubungan asosiasi antara kemampuan kognitif matematika dan task commitment siswa KKO SMA negeri se-DIY.

\section{METODE}

Penelitian ini menggunakan metode survei. Pengambilan data dilaksanakan pada tanggal 31 Juli31 Oktober 2018. Penelitian dilakukan di delapan SMA negeri yang ditunjuk untuk menyelenggarakan kelas KKO oleh pemerintah daerah DIY yaitu SMA Negeri 4 Yogyakarta, SMA Negeri 2 Ngaglik, SMA Negeri 1 Seyegan, SMA Negeri 1 Sewon, SMA Negeri 2 Playen, SMA Negeri 1 Tanjungsari, SMA Negeri 1 Pengasih dan SMA Negeri 1 Lendah. Sekolah tersebut terletak di lima kabupaten/kota yaitu Kota Yogyakarta, Kabupaten Bantul, Sleman, Kulon Progo, dan Gunungkidul.

Populasi pada penelitian ini yaitu siswa KKO kelas X SMA negeri se-DIY tahun ajaran 2018/2019 yang berjumlah 319 siswa. Sampel penelitian berjumlah 132 siswa ditentukan dengan teknik sampel acak proporsional sistematik. Teknik acak digunakan untuk menentukan kelas yang menjadi sampel penelitian. Teknik proporsional digunakan untuk menghitung besar sampel proporsi setiap kelas dengan menggunakan rumus alokasi proporsional (Riduwan, 2006, p. 66) seperti pada Persamaan 1.

$\mathrm{n}_{\mathrm{i}}=\frac{\mathrm{N}_{\mathrm{i}} \cdot \mathrm{n}}{\mathrm{N}}$

Berdasarkan Persaman $1, \mathrm{n}_{\mathrm{i}}$ adalah jumlah sampel siswa untuk setiap kelas, $\mathrm{n}$ adalah jumlah sampel keseluruhan, $\mathrm{N}_{\mathrm{i}}$ merupakan jumlah populasi siswa untuk setiap kelas, dan $\mathrm{N}$ yaitu jumlah populasi keseluruhan. Selanjutnya, teknik sistematik digunakan untuk menentukan sampel responden. Menurut (Cohen, Manion, \& Morrison, 2002) pemilihan sampel sistematik diawali dengan memilih titik awal secara acak. Untuk mendapatkan data yang dapat mewakili, data di urutkan terlebih dahulu berdasarkan nilai yang diperoleh siswa.

Teknik pengumpulan data yang digunakan dalam penelitian ini menggunakan instrumen tes dan angket. Metode tes diberikan untuk menilai kemampuan kognitif matematika siswa yang meliputi tiga aspek yaitu pengetahuan, penerapan dan penalaran. Soal tes kemampuan kognitif matematika berupa soal pilihan ganda dan uraian sebanyak 15 butir yang terdiri dari 10 soal pilihan ganda dan 5 soal uraian. 
Soal tersebut diberikan satu kali dan dikerjakan dalam waktu 90 menit. Adapun kisi-kisi instrumen tes kemampuan kognitif matematika siswa disajikan pada Tabel 2.

Tabel 2. Kisi-Kisi Tes Kemampuan Kognitif

\begin{tabular}{ll}
\hline \multicolumn{1}{c}{ Aspek } & \\
\hline Pengetahuan & Mengurutkan \\
& Menghitung \\
Penerapan & Menyelesaikan masalah rutin \\
& Memodelkan \\
Penalaran & Menganalisis \\
& Memberikan alasan \\
\hline
\end{tabular}

Pengumpulan data dengan metode angket diberikan untuk menilai task commitment siswa yang meliputi aspek ketekunan, ketahanan, percaya diri, dedikasi pada latihan, dan minat. Angket yang digunakan berupa instrumen angket tertutup yang terdiri dari 30 butir pernyataan dan sudah disediakan pilihan jawabannya. Instrumen angket tersebut juga diberikan satu kali. Adapun kisi-kisi instrumen angket task commitment siswa disusun dengan indikator mengacu pada (Kiran \& Murthy, 2016, pp. 123-124) yang disajikan pada Tabel 3.

Tabel 3. Kisi-Kisi Angket Task Commitment

\begin{tabular}{ll}
\hline \multicolumn{1}{c}{ Aspek } & \multicolumn{1}{c}{ Indikator } \\
\hline Ketekunan & Pengendalian diri terhadap kegiatan akademik \\
& Keingintahuan pada bidang akademik \\
Ketahanan & Ingatan \\
& Memecahkan masalah \\
Percaya diri & Harga diri \\
& Keberanian \\
Dedikasi pada latihan & Perencanaan belajar yang realistis \\
& Manajemen waktu yang efektif \\
Minat & Berpikir terus menerus tentang kegiatan akademik \\
& Terus menerus mengejar sesuatu yang lebih tinggi \\
\hline
\end{tabular}

Kedua instrumen penelitian tersebut selanjutnya dibuktikan validitas dan diestimasi reliabilitasnya sebelum digunakan. Validitas dan reliabilitas perlu dilakukan dengan tujuan agar hasil penelitian benar-benar mencerminkan keadaan yang sesungguhnya dari subjek yang akan diteliti. Validitas yang digunakan dalam penelitian ini adalah validitas isi. Validitas isi ditetapkan oleh penilaian ahli yaitu dua orang dosen Pendidikan Matematika, Program Pascasarjana UNY. Berdasarkan validasi oleh ahli instrumen tes dan angket dinyatakan valid setelah direvisi berdasarkan masukan ahli tersebut. Selain divalidasi, instrumen tes juga dianalisis karakteristik butirnya menggunakan bantuan software iteman. Berdasarkan hasil analisis, diperoleh indeks kesulitan Mean $P=0,047$ dan nilai daya pembeda Mean Rpbis $=0,440$. Hal tesebut menunjukkan bahwa butir soal berada pada kategori baik. Selanjutnya, estimasi reliabilitas instrumen tes kemampuan kognitif matematika bentuk pilihan ganda dilakukan dengan program iteman. Hasilnya menunjukkan nilai alpha yaitu 0,777 dan nilai SEM yaitu 1,247. Sedangkan bentuk soal uraian diestimasi dengan SPSS dan hasilnya menunjukkan nilai cronbach's alpha yaitu 0,892 dengan nilai SEM sebesar 1,67. Berdasarkan hasil tersebut instrumen tes dinyatakan reliabel. Hasil estimasi reliabilitas instrumen angket task commitment juga menunjukkan hasil yang reliabel dengan nilai cronbach's alpha sebesar 0,915, dengan nilai SEM sebesar 4,524.

Analisis data dalam penelitian ini menggunakan bantuan program SPSS dan Microsoft Excel. Adapun langkah-langkah yang digunakan untuk melakukan analisis data yaitu membuat tabulasi skor data, mengonversi skor kemampuan kognitif matematika dan task commitment siswa menjadi tiga kategori dengan menggunakan kriteria menurut (Ebel \& Frisbie, 1991, p. 280) pada Tabel 4.

Tabel 4. Kriteria Konversi Data

\begin{tabular}{cc}
\hline Interval & Kategori \\
\hline $\mathrm{X} \geq \overline{\mathrm{X}}+0,5 \mathrm{~s}$ & Tinggi \\
$\overline{\mathrm{X}}-0,5 \mathrm{~s} \leq \mathrm{X}<\overline{\mathrm{X}}+0,5 \mathrm{~s}$ & Sedang \\
$\mathrm{X}<\overline{\mathrm{X}}-0,5 \mathrm{~s}$ & Rendah \\
\hline
\end{tabular}


Berdasarkan Tabel 4, diketahui bahwa $X$ merupakan nilai skor siswa, $\bar{X}$ adalah nilai rata-rata skor siswa, dan $s$ adalah simpangan baku. Data selanjutnya dianalisis menggunakan rumus Chi-Kuadrat untuk menyelidiki ada tidaknya hubungan atau asosiasi atau kaitan antar faktor, serta untuk menguji independen antara dua faktor di dalam daftar kontingensi baris dan kolom (Sudjana, 2005, pp. 272278). Langkah selanjutnya yaitu menentukan seberapa besar derajat hubungan antara dua faktor yang terdiri dari beberapa kategori menggunakan rumus koefisien kontingensi $C$. Selanjutnya harga $C$ dibandingkan dengan koefisien kontingensi maksimum $\left(\mathrm{C}_{\text {maks }}\right)$ kemudian mencari nilai koefisien kontingensi terstandarisasi $\left(C_{s}\right)$ berdasarkan rumus Persamaan 2 dari (Blaikie, 2003, p. 100).

$C_{s}=\frac{C}{C_{\text {maks }}}$

Persamaan 2 tersebut diketahui bahwa $C_{s}$ adalah koefisien kontingensi terstandarisasi. $C$ adalah koefisien kontingensi hitung. Dan $C_{\text {maks }}$ merupakan koefisien kontingensi maksimum. Interpretasi nilai koefisien kontingensi menurut (Blaikie, 2003) dapat dikonsultasikan dalam Tabel 5.

Tabel 5. Interpretasi Nilai Koefisien Kontingensi

\begin{tabular}{|c|c|}
\hline Koefisien & Tingkat Asosiasi \\
\hline 0,00 & Tidak ada (none) \\
\hline $0,01-0,09$ & Sangat lemah/dapat di abaikan (negligible) \\
\hline $0,10-0,29$ & Lemah (weak) \\
\hline $0,30-0,59$ & Cukup kuat (moderate) \\
\hline $0,60-0,74$ & Kuat (strong) \\
\hline $0,75-0,99$ & Sangat kuat (very strong) \\
\hline 1,00 & Sempurna (perfect) \\
\hline
\end{tabular}

\section{HASIL DAN PEMBAHASAN}

\section{Hasil}

Task Commitment Siswa

Instrumen angket task commitment siswa diberikan kepada 132 siswa responden. Indikator task commitment siswa diuraikan menjadi 30 butir pernyataan dengan skor setiap item 1-5, sehingga rentang skor task commitment siswa yaitu 30-150. Selanjutnya, pengategorisasian dilakukan dengan kriteria pada Tabel 6.

Tabel 6. Kategori Task Commitment Siswa

\begin{tabular}{cc}
\hline Interval & Kategori \\
\hline $150 \geq x \geq 102$ & Tinggi \\
$89 \leq x<102$ & Sedang \\
$30 \leq x<89$ & Rendah \\
\hline
\end{tabular}

Adapun statistik deskriptif task commitment siswa KKO SMA negeri se-DIY disajikan Tabel 7.

Tabel 7. Statistik Deskriptif Task Commitment

\begin{tabular}{lcc}
\hline & Statistik Deskriptif & Nilai \\
\hline Rata-rata & & 95,63 \\
Standar Deviasi & 12,33 \\
Nilai Tertinggi & 138,00 \\
Nilai Terendah & 59,00 \\
Banyak Siswa & 132 \\
\hline
\end{tabular}

Berdasarkan data pada Tabel 7, task commitment siswa KKO SMA negeri se-DIY termasuk dalam kategori sedang. Hal ini juga ditunjukkan dari hasil distribusi frekuensi dan persentase banyak siswa pada setiap kategori task commitment dapat dilihat pada Tabel 8.

Berdasarkan Tabel 8 dapat diketahui bahwa task commitment siswa KKO SMA negeri se-DIY pada kategori tinggi sebanyak 40 siswa $(30,3 \%)$, sedang sebanyak 54 siswa $(40,9 \%)$ dan rendah sebanyak 38 siswa $(28,8 \%)$. Selanjutnya, deskripsi task commitment siswa KKO SMA negeri Se-DIY berdasarkan aspek disajikan pada Tabel 9 . 
Jurnal Riset Pendidikan Matematika, 6 (1), 2019 - 19

Nurafni Retno Kurniasih, Idris Harta

Tabel 8. Distribusi Frekuensi dan Persentase Kategori Task Commitment

\begin{tabular}{lccc}
\hline & Kategori & Frekuensi & Persentase \\
\hline Tinggi & 40 & $30,3 \%$ \\
Sedang & 54 & $40,9 \%$ \\
Rendah & 38 & $28,8 \%$ \\
Jumlah & 132 & $100 \%$ \\
\hline
\end{tabular}

Tabel 9. Distribusi Frekuensi dan Persentase Kategori Task Commitment Berdasarkan Aspek

\begin{tabular}{|c|c|c|c|c|c|c|c|c|}
\hline \multirow{3}{*}{ Aspek } & \multicolumn{6}{|c|}{ Hasil } & \multirow{2}{*}{\multicolumn{2}{|c|}{ Total }} \\
\hline & \multicolumn{2}{|c|}{ Tinggi } & \multicolumn{2}{|c|}{ Sedang } & \multicolumn{2}{|c|}{ Rendah } & & \\
\hline & $\sum$ & $\%$ & $\Sigma$ & $\%$ & $\sum$ & $\%$ & $\Sigma$ & $\%$ \\
\hline Ketekunan & 40 & 30,3 & 50 & 37,9 & 42 & 31,8 & 132 & 100 \\
\hline Ketahanan & 35 & 26,5 & 51 & 38,6 & 46 & 34,8 & 132 & 100 \\
\hline Percaya Diri & 31 & 23,5 & 66 & 50,0 & 35 & 26,5 & 132 & 100 \\
\hline Dedikasi Pada Latihan & 35 & 26,5 & 64 & 48,5 & 33 & 25,0 & 132 & 100 \\
\hline Minat & 37 & 28,0 & 62 & 47,0 & 33 & 25,0 & 132 & 100 \\
\hline
\end{tabular}

Berdasarkan Tabel 9, secara keseluruhan dapat dilihat bahwa siswa KKO SMA se-DIY sebagian besar berada pada kategori sedang dan rendah untuk masing-masing aspek task commitment yaitu aspek ketekunan, ketahanan, percaya diri, dedikasi pada latihan dan minat.

Kemampuan Kognitif Matematika

Instrumen tes kemampuan kognitif matematika siswa diberikan kepada 132 siswa responden. Topik pada tes ini yaitu persamaan dan pertidaksamaan nilai mutlak linear satu variabel serta pertidaksamaan rasional dan irasional satu variabel. Rentang skor kemampuan kognitif matematika siswa yaitu 0-100. Selanjutnya, pengategorisasian dilakukan dengan kriteria pada Tabel 10.

Tabel 10. Kategori Kemampuan Kognitif

\begin{tabular}{cc}
\hline Interval & Kategori \\
\hline $100 \geq \mathrm{x} \geq 51$ & Tinggi \\
$30 \leq \mathrm{x}<51$ & Sedang \\
$0 \leq \mathrm{x}<30$ & Rendah \\
\hline
\end{tabular}

Adapun deskripsi kemampuan kognitif matematika siswa KKO SMA negeri se-DIY dijelaskan pada Tabel 11.

Tabel 11. Statistik Deskriptif Kemampuan Kognitif Matematika

\begin{tabular}{lcc}
\hline & Statistik Deskriptif & Nilai \\
\hline Rata-Rata & & 40,62 \\
Standar Deviasi & 20,59 \\
Nilai Tertinggi & 92,00 \\
Nilai Terendah & 5,00 \\
Banyak Siswa & 132 \\
\hline
\end{tabular}

Berdasarkan data pada Tabel 11, kemampuan kognitif matematika siswa KKO SMA negeri seDIY termasuk dalam kategori sedang. Selanjutnya ditunjukkan pada hasil distribusi frekuensi dan persentase banyak siswa pada setiap kategori kemampuan kognitif matematika siswa pada Tabel 12 .

Tabel 12. Distribusi Frekuensi dan Persentase Kategori Kemampuan Kognitif Matematika

\begin{tabular}{|c|c|c|}
\hline Kategori & Frekuensi & Persentase \\
\hline Tinggi & 44 & $33,3 \%$ \\
\hline Sedang & 40 & $30,3 \%$ \\
\hline Rendah & 48 & $36,4 \%$ \\
\hline Jumlah & 132 & $100 \%$ \\
\hline
\end{tabular}

Berdasarkan Tabel 12 dapat diketahui bahwa secara keseluruhan kemampuan kognitif matematika siswa KKO SMA negeri se-DIY pada kategori tinggi sebanyak 44 siswa $(33,3 \%)$, sedang 
sebanyak 40 siswa (30,3\%) dan rendah sebanyak 48 siswa (36,4\%). Selanjutnya, deskripsi kemampuan kognitif matematika siswa KKO SMA negeri Se-DIY berdasarkan aspek dijelaskan pada Tabel 13.

Tabel 13. Distribusi Frekuensi dan Persentase Kategori Kemampuan Kognitif Matematika Berdasarkan Aspek

\begin{tabular}{|c|c|c|c|c|c|c|c|c|}
\hline \multirow{3}{*}{ Aspek } & \multicolumn{6}{|c|}{ Hasil } & \multirow{2}{*}{\multicolumn{2}{|c|}{ Total }} \\
\hline & \multicolumn{2}{|c|}{ Tinggi } & \multicolumn{2}{|c|}{ Sedang } & \multicolumn{2}{|c|}{ Rendah } & & \\
\hline & $\Sigma$ & $\%$ & $\Sigma$ & $\%$ & $\Sigma$ & $\%$ & $\Sigma$ & $\%$ \\
\hline Pengetahuan & 35 & 26,5 & 60 & 45,5 & 37 & 28,0 & 132 & 100 \\
\hline Penerapan & 44 & 33,3 & 44 & 33,3 & 44 & 33,3 & 132 & 100 \\
\hline Penalaran & 40 & 30,3 & 33 & 25,0 & 59 & 44,7 & 132 & 100 \\
\hline
\end{tabular}

Berdasarkan Tabel 13, dapat dilihat bahwa kemampuan kognitif matematika siswa untuk masingmasing aspek yaitu pengetahuan, penerapan, dan penalaran masih didominasi oleh siswa dengan kemampuan sedang dan rendah, bahkan untuk aspek penalaran, hampir $60 \%$ siswa kemampuannya berada pada kategori rendah.

\section{Hubungan antara Kemampuan Kognitif dan Task Commitment}

Langkah awal untuk melakukan uji hipotesis ialah dengan melakukan uji prasyarat analisis yaitu uji normalitas. Hasil perhitungan uji normalitas data task commitment siswa diperoleh sig 0,872 sedangkan kemampuan kognitif matematika siswa diperoleh sig 0,410 . Berdasarkan hasil perhitungan, dapat diketahui bahwa sebaran data task commitment dan kemampuan kognitif matematika dinyatakan normal karena nilai signifikansi kedua data variabel tersebut lebih besar dari 0,05. Dengan kata lain, data telah memenuhi syarat untuk dilakukan analisis lanjutan.

Data selanjutnya dianalisis menggunakan prosedur perhitungan chi-kuadrat. Berdasarkan tabel nilai-nilai kritis chi-kuadrat, dengan derajat kebebasan 4 dan taraf signifikansi 5\% diperoleh nilai $\chi^{2}$ tabel $=9,488$. Selanjutnya disusun tabel kontingensi menggunakan bantuan program SPSS dan diperoleh $\chi^{2}$ hitung $=10,22428$. Sehingga dapat disimpulkan bahwa $\chi^{2}$ hitung $\geq \chi^{2}$ tabel maka $\mathbf{H}_{\mathbf{0}}$ ditolak. Artinya terdapat hubungan antara kemampuan kognitif matematika dengan task commitment siswa KKO SMA negeri se-DIY.

Selanjutnya, untuk mengetahui derajat hubungan antara faktor satu dengan yang lainnya, digunakan rumus koefisien kontingensi C. Berdasarkan hasil perhitungan, diperoleh harga $\mathrm{C}$ yaitu 0,268 dan $C_{\text {maks }}$ 0,816. Selanjutnya berdasarkan interpretasi nilai $C_{s}$ menurut Blaikie (2003, p. 100), nilai 0,328 berada pada interval 0,30-0,59 yang berarti tingkat asosiasinya cukup kuat (moderate). Artinya hubungan atau asosiasi antara kemampuan kognitif matematika dengan task commitment siswa KKO SMA negeri se-DIY cukup kuat.

\section{Pembahasan}

\section{Task Commitment Siswa KKO}

Task commitment dalam penelitian ini menjelaskan tentang kekuatan dari dalam diri siswa untuk menyelesaikan tugas dan memecahkan masalah untuk meraih prestasi tertentu yang diukur berdasarkan aspek ketekunan, ketahanan, percaya diri, dedikasi pada latihan, dan minat. Hasil penelitian ini menjelaskan bahwa task commitment siswa KKO SMA negeri se-DIY secara keseluruhan berada dalam kategori sedang yaitu sebanyak 40,9\% siswa. Adapun task commitment siswa pada kategori tinggi sebanyak $30,3 \%$ dan kategori rendah sebanyak $28,8 \%$. Hasil ini senada dengan penelitian Najamuddin, Idris, \& Afiif (2015, p. 163) bahwa task commitment siswa berada pada kategori sedang dengan persentase $65 \%$. Hal ini dimungkinkan karena guru jarang menguji task commitment siswa KKO dan melakukan evaluasi terhadap aspek afektif siswa tersebut. Pendapat ini dikuatkan oleh hasil penelitian Urhahne (2011) yang mengatakan bahwa guru hanya akurat dalam menilai kinerja siswa namun tidak dapat menilai kreativitas dan task commitment siswa dengan benar.

Hasil penelitian ini juga menunjukkan bahwa task commitment siswa pada aspek ketekunan berada pada kategori sedang. Dalam mencapai tujuan keberhasilan belajar matematika yang optimal, siswa KKO hendaknya memiliki ketekunan yang tinggi dari dalam diri mereka. Terlepas dari beban tugas siswa KKO sebagai atlit, kesulitan yang dialami siswa KKO pada pembelajaran matematika akan dapat diatasi dengan memiliki ketekunan. Berdasarkan hasil penelitian, masih terdapat $31,8 \%$ siswa 
yang memiliki ketekunan rendah. Hal ini terjadi karena siswa mudah menyerah apabila ada tugas matematika yang sulit, berhenti mempelajari matematika ketika terasa berat, dan ketika siswa sudah lelah mereka sudah tidak berkeinginan untuk mengikuti pembelajaran. Selain itu, siswa dengan dengan ketekunan rendah tidak memperhatikan guru saat pembelajaran berlangsung, hanya memiliki satu buku referensi atau LKS, bahkan ada siswa yang sama sekali tidak memiliki buku maupun LKS matematika. Beberapa sekolah di DIY memang tidak mewajibkan siswa untuk membeli buku dan LKS namun siswa diperbolehkan meminjam buku referensi dari perpustakaan secara gratis. Akan tetapi, siswa tersebut hanya mengandalkan materi matematika yang disampaikan guru dan tidak berusaha untuk mempergunakan fasilitas perpustakaan yang telah disediakan sekolah.

Task commitment siswa pada aspek ketahanan termasuk kategori sedang. Memiliki ketahanan merupakan salah satu aspek yang harus dimiliki siswa KKO. Hal ini dikarenakan memiliki ketahanan ingatan yang baik menjadikan penyampaian materi matematika pada proses pembelajaran lebih lancar. Berdasarkan hasil analisis, sebanyak 34,8\% siswa masih berada pada kategori rendah. Kenyataan yang terjadi di lapangan menunjukkan bahwa siswa mudah lupa materi yang telah dipelajari minggu lalu, tidak dapat menduga dengan cepat langkah-langkah penyelesaian dari tugas yang disampaikan guru, masih kesulitan memahami materi dan memecahkan soal matematika yang disampaikan guru dalam pembelajaran, serta merasa tertekan saat memecahkan masalah matematika.

Selanjutnya, task commitment siswa pada aspek percaya diri menunjukkan kategori sedang. Siswa KKO SMA negeri se-DIY dengan percaya diri tinggi yaitu sebesar $23,5 \%$. Hal ini sesuai dengan kenyataan di lapangan bahwa siswa tidak takut salah dalam menjawab permasalahan matematika. Siswa yakin dengan kemampuan yang dimilikinya dan dapat mengandalkan diri sendiri untuk mengerjakan tugas matematika. Sementara itu 26,5\% siswa dengan percaya diri rendah dan 50\% siswa dengan percaya diri sedang terlihat tidak yakin dengan kemampuan yang dimilikinya yang selanjutnya ditandai dengan menyontek teman, berdiskusi dengan teman saat tes kemampuan sedang berlangsung, serta melanggar peraturan tes kemampuan karena menggunakan gawai.

Hasil penelitian ini juga menunjukkan bahwa task commitment siswa pada aspek dedikasi pada latihan berada pada kategori sedang. Dalam mencapai tujuan keberhasilan belajar matematika yang optimal, siswa KKO hendaknya memiliki dedikasi pada latihan yang tinggi. Meskipun siswa KKO membutuhkan banyak waktu untuk mengembangkan bakatnya di bidang olahraga namun kewajiban siswa KKO untuk mempelajari materi yang sudah diatur dalam kurikulum sekolah tetap harus dilaksanakan dengan baik. Task commitment siswa pada aspek dedikasi pada latihan menunjukkan bahwa sebanyak $26,5 \%$ berada pada kategori tinggi. Siswa dengan dedikasi pada latihan tinggi membuat jadwal belajar matematika, berlatih menyelesaikan soal-soal lain yang serupa dengan soal pada tugas matematika yang diberikan guru, rajin mengerjakan latihan soal matematika yang diberikan guru dalam pembelajaran, dapat memanfaatkan waktu luang untuk belajar matematika, tidak menunda-nunda melaksanakan tugas matematika yang diberikan guru serta hanya terfokus mempelajari mata pelajaran matematika ketika pembelajaran matematika berlangsung, tidak mengerjakan tugas dari mata pelajaran lan. Sementara itu 25\% siswa masih berada pada kategori rendah dalam dedikasi pada latihan.

Pada aspek minat menunjukkan berada pada kategori sedang. Minat dalam matematika, tugas matematika dan pembelajaran matematika merupakan hal yang penting dimiliki siswa KKO. Task commitment siswa pada aspek minat menunjukkan bahwa $28 \%$ siswa berada pada kategori tinggi. Hal ini ditunjukkan dengan siswa yang lebih menyukai pelajaran matematika dibandingkan dengan pelajaran lain, sering lupa waktu saat asyik mengerjakan soal-soal matematika, tidak ingin jam pembelajaran matematika segera berakhir, senang mengikuti jam tambahan matematika, melaksanakan tugas matematika dengan baik dengan suka rela, dan sudah mempersiapkan diri sebelum pembelajaran matematika dimulai. Sementara itu 25\% siswa di lapangan yang menunjukkan kategori minat rendah tidak menunjukkan tingkat kekuatan yang tinggi untuk mengikuti pembelajaran matematika. Siswa tersebut izin keluar ruangan untuk sekedar pergi ke kamar kecil, mengambil air minum, membuang sampah, dan meminjam alat tulis teman. Selain itu juga ada siswa yang meminta izin untuk mengikuti pertemuan club, technical meeting dan izin dispensasi.

Lima aspek dalam task commitment yaitu ketekunan, ketahanan, percaya diri, dedikasi pada latihan, dan minat dalam pembelajaran matematika perlu dimiliki oleh siswa KKO. Hal ini sesuai dengan pendapat Tayibu (2016) bahwa siswa yang memiliki task commitment memiliki hasil belajar tinggi. Hasil task commitment siswa KKO SMA negeri se-DIY dalam penelitian ini masih berada pada kategori sedang. Hasil ini akan lebih baik jika sesuai dengan pendapat McCaul, Hinsz, \& McCaul (1987, p. 437) 
yang mengatakan bahwa siswa dengan komitmen tinggi akan cenderung lebih berhasil dalam mencapai tujuan mereka dibandingkan dengan siswa dengan komitmen rendah.

Adapun cara untuk meningkatkan task commitment yaitu dengan meningkatkan motivasi belajar siswa. Hal ini sesuai dengan pendapat Park \& Lee (2011, p. 977) dan diperkuat oleh Kerr (2009, p. 490) bahwa motivasi dapat mempengaruhi partisipasi siswa di kelas, task commitment, dan jumlah kesenangan yang mereka dapatkan dari belajar. Selain itu, perlu adanya persepsi yang baik dari guru terhadap siswa KKO. Hal ini disampaikan oleh Widanarti (2016) bahwa persepsi guru terhadap siswa KKO dalam mengikuti pembelajaran di SMA Negeri 4 Yogyakarta tergolong dalam kategori rendah yaitu sebanyak 40\% (12 guru). Apabila siswa mampu mengoptimalkan kekuatan dari dalam diri untuk menyelesaikan tugas dan memecahkan masalah dalam pembelajaran matematika, maka kemampuan kognitif siswa pada pembelajaran matematika yang ditunjukkan oleh hasil belajar siswa akan tinggi pula.

\section{Kemampuan Kognitif Matematika Siswa KKO}

Kemampuan kognitif siswa KKO SMA negeri se-DIY terdiri dari tiga aspek yaitu pengetahuan, penerapan dan penalaran. Ketiga aspek tersebut mencakup kemampuan berpikir tingkat rendah dan berpikir tingkat tinggi. Tes kemampuan kognitif matematika siswa dilakukan untuk mengetahui level kemampuan kognitif matematika siswa.

Berdasarkan hasil analisis data kemampuan kognitif siswa KKO SMA negeri se-DIY menunjukkan bahwa secara keseluruhan rata-rata kemampuan kognitif matematika siswa yaitu 40,62. Hasil tersebut menunjukkan bahwa kemampuan kognitif matematika siswa SMA negeri se-DIY berada dalam kategori sedang. Adapun hasil distribusi frekuensi siswa yang berada pada kategori tinggi yaitu $33,3 \%$, sedang $30,3 \%$ dan rendah $36,4 \%$ siswa. Hasil ini hampir sama dengan penelitian yang dilakukan oleh Lestari (2016, p. 820) yang memberikan kesimpulan bahwa kemampuan kognitif siswa berdasarkan gender berada pada kategori sedang.

Berdasarkan hasil penelitian, kemampuan kognitif matematika siswa pada aspek pengetahuan berada pada kategori sedang, pada aspek penerapan berada pada kategori sedang dan pada aspek penalaran berada pada kategori rendah. Hasil ini senada dengan Sari, Amilda, \& Syutaridho (2017, p. 160) bahwa ketercapaian nilai kemampuan kognitif siswa pada kategori analisis paling rendah dibandingkan dengan kategori mengingat, memahami dan mengaplikasikan. Namun hasil penelitian ini berbanding terbalik dengan hasil penelitian Ceylan (2013, p. 35) yang mengatakan bahwa skor rata-rata domain penalaran siswa lebih tinggi daripada domain pengetahuan dan penerapan. Kemampuan penerapan siswa dominan dilatihkan pada soal-soal dalam buku BSE (Buku Sekolah Elektronik) serta pada soal UN (Barmoyo \& Wasis, 2014, p. 8) sehingga soal-soal tersebut sudah tidak asing lagi bagi siswa.

Rendahnya penalaran siswa KKO SMA negeri se-DIY dimungkinkan terjadi karena soal atau masalah yang diberikan kepada siswa merupakan masalah non-rutin yang belum dikenal siswa. Penyelesaian soal yang membutuhkan beberapa langkah yang bahkan menggunakan pengetahuan dan pemahaman dari berbagai bidang matematika belum dapat dikuasai siswa KKO. Hasil ini diperkuat oleh penelitian Asmara, Waluya, \& Rochmad (2017, p. 141) bahwa siswa masih belum terbiasa dengan soalsoal maupun permasalahan yang membutuhkan pemikiran logis serta solusi aplikatif, siswa masih terbiasa dengan jawaban yang prosedural dan bersifat konkret. Hal ini didukung oleh Huda (2012, p. 75) bahwa salah satu faktor internal penyebab siswa tidak mampu menggunakan kemampuan kognitif tingkat tinggi seperti penalaran yaitu siswa kurang latihan menyelesaikan soal yang menuntut untuk menggunakan kemampuan kognitif tingkat tinggi sehingga siswa tidak terbiasa menghadapi soal serupa. Selain itu, guru juga jarang memberikan soal yang membutuhkan kemampuan penalaran. Hasil ini didukung oleh penelitian Kartikasari, Kusmayadi, \& Usodo (2016, p. 440) bahwa soal yang disusun guru senior dan pemula sebagian besar hanya pada tingkatan aplikasi/penerapan. Soal yang disusun guru pemula dapat langsung diselesaikan siswa dengan langkah-langkah penyelesaian yang familier serta dapat diselesaikan tanpa harus menafsirkan maksud soal. Bietenbeck $(2014$, p. 10) mencatat bahwa hanya sebagian kecil dari pertanyaan dalam tes pada umumnya yang mengukur kemampuan penalaran siswa. Siswa juga mengaku tidak belajar sebelum tes kemampuan kognitif dilaksanakan. Hal ini dibuktikan oleh tulisan siswa pada lembar jawab soal aspek penalaran yang mengatakan bahwa "karena soal ini sangat sulit dan saya belum bisa, saya hanya mengerjakan begitu, mohon dimaklumi", "maaf saya tidak bisa mengerjakan bu", "Karena soal ini belum pernah diajarkan oleh bu Im (guru matematika 
siswa KKO) jadi saya tidak bisa mengerjakannya" dan "jujur saya gak pernah belajar karena kecapekan latihan (olahraga)"

Kemampuan kognitif matematika sangat penting dimiliki oleh siswa ketika menghadapi materi baru dalam pembelajaran, di mana siswa harus mempelajari prosedur atau teknik baru selama proses pembelajaran berlangsung. Hal ini menjadi pondasi siswa untuk membangun pengetahuan yang lebih tinggi. Pendapat ini dikuatkan oleh Munandar, 2014 (pp. 126-127) bahwa kemampuan kognitif dan ingatan yang berkaitan dengan penerimaan dan pengenalan kembali materi diperlukan karena setiap proses pemikiran harus menggunakan fakta dan gagasan yang telah dipelajari sebelumnya. Kedua kemampuan tersebut merupakan dasar bagi proses pemikiran yang lebih tinggi. Dengan memberikan soal tes kemampuan kognitif matematika kepada siswa, siswa akan terbiasa menggunakan kemampuan pengetahuan, penerapan dan penalarannya dalam menyelesaikan masalah dalam matematika yang kemudian dapat pula memberikan dampak positif bagi diri pribadi siswa KKO. Hal ini disampaikan pula oleh Thompson (2012, p. 25) bahwa kurangnya kemampuan kognitif menyebabkan individu lemah dalam bidang akademik, keterampilan, sosial, serta membuat individu lebih rentan terhadap pengaruh kriminal dan perilaku merusak diri sendiri.

Kemampuan kognitif matematika dapat ditingkatkan dengan lebih memperhatikan kemampuan afektif siswa dalam hal ini yaitu task commitment. Pendapat tersebut merupakan implikasi dari penelitian (Veloo et al., 2014, p. 619) yang menyimpulkan bahwa guru jarang mengukur kemampuan afektif siswa, tetapi mereka terus memberikan prioritas untuk mengukur kemampuan kognitif. Hal tersebut menunjukkan betapa pentingnya kemampuan afektif pada kemampuan kognitif yang membantu siswa secara langsung untuk meningkatkan belajar matematika mereka.

\section{Kemampuan Kognitif Matematika Berdasarkan Task Commitment Siswa KKO}

Hasil analisis data penelitian tentang kemampuan kognitif matematika dan task commitment siswa membuktikan bahwa terdapat hubungan yang cukup kuat antara kemampuan kognitif matematika dengan task commitment siswa KKO SMA negeri se-DIY dan hal itu memang mencerminkan keadaan siswa yang sebenarnya tidak disebabkan oleh adanya faktor kesalahan pengambilan sampel maupun faktor kebetulan. Hal ini dibuktikan dengan nilai $\chi^{2}$ hitung sebesar 10,22428 dan $\chi^{2}$ tabel sebesar 9,488 menggunakan taraf signifikansi 5\%. Hasil ini sesuai dengan pendapat Santos \& Barmby (2010, p. 200) yang mengatakan bahwa komitmen sangat penting karena berhubungan dengan prestasi akademik siswa. Hasil ini juga menguatkan pendapat Subotnik, Olszewski-Kubilius, \& Worrell (2011, p. 18) bahwa task commitment berkontribusi terhadap kinerja yang luar biasa yang dalam hal ini yaitu kemampuan kognitif matematika siswa.

Kemampuan kognitif matematika siswa berkaitan dengan hasil belajar matematika siswa. Hal ini dikarenakan adanya interaksi antara tujuan pembelajaran dengan kemampuan kognitif. Pendapat ini dikuatkan oleh Latham, Seijts, \& Crim (2008, p. 222). National Research Council dalam (Kilpatrick, Swafford, \& Findell, 2001, p. 9) juga mengatakan bahwa kemampuan matematika hendaknya dimiliki untuk menggambarkan kesuksesan pembelajaran matematika. Selanjutnya menurut Phillipson \& Phillipson (2012, p. 496), kemampuan kognitif merupakan prediktor prestasi dalam banyak mata pelajaran akademik, termasuk matematika.

Hasil penelitian ini diperkuat oleh penelitian Hakim (2017, p. 24) yang menyimpulkan bahwa terdapat pengaruh yang signifikan komitmen diri siswa terhadap prestasi belajar matematika. Senada dengan Hakim, (Tayibu, 2016, p. 132) juga menyimpulkan bahwa task commitment berpengaruh signifikan terhadap hasil belajar matematika dengan taraf kepercayaan 98\%. Selanjutnya (Mufidah, Suharto, \& Setiawan, 2018, p. 49) juga menyimpulkan hasil bahwa task commitment memiliki pengaruh sebesar 3,1\% terhadap hasil belajar matematika. Pianyta (2017, p. 80) menyimpulkan hal yang senada bahwa terdapat pengaruh yang signifikan antara task commitment terhadap prestasi belajar matematika, yaitu sebesar $16,5 \%$.

Hasil perhitungan derajat hubungan menggunakan rumus koefisien kontingensi antara task commitment dengan kemampuan kognitif matematika menunjukkan nilai $C=0,268$ dan $C_{\text {maks }}=0,816$. Selanjutnya nilai $C_{s}$ yaitu 0,328 . Semakin jauh harga $C$ dari $C_{\text {maks }}$, semakin kecil derajat hubungan atau asosiasi antar faktor. Dengan kata lain, faktor satu dengan yang lain akan semakin kurang berkaitan. Berdasarkan hasil perhitungan tersebut, nilai $C_{s}$ berada pada interval 0,30-0,59 yang berarti tingkat asosiasinya cukup kuat. Artinya hubungan atau asosiasi antara kemampuan kognitif matematika dengan task commitment siswa KKO SMA negeri se-DIY cukup kuat. Hasil ini kontradiksi dengan penelitian 
Firmanto (2013, p. 26) bahwa variabel task commitment, kecerdasan dan kreativitas memiliki kontribusi kuat terhadap prestasi belajar matematika, bahasa Inggris dan IPA. Adapun task commitment dan kecerdasan merupakan prediktor utama prestasi belajar bagi siswa perempuan, sementara prediktor utama prestasi belajar siswa laki-laki hanya aspek kecerdasan.

Selanjutnya, hasil perhitungan uji chi-kuadrat dengan menggunakan tabel kontingensi dalam penelitian menunjukkan bahwa paling banyak kelompok siswa dengan task commitment rendah, rendah pula pada kemampuan kognitif matematika $(15,9 \%)$. Dari kelompok siswa dengan task commitment tinggi, paling banyak siswa dengan kemampuan kognitif matematika sedang $(11,4 \%)$ dibandingkan dengan siswa dengan kemampuan kognitif matematika tinggi $(10,6 \%)$ dan rendah $(8,3 \%)$. Sehingga dapat dikatakan, kelompok siswa dengan task commitment tinggi memiliki kemampuan kognitif matematika sedang. Sementara itu, dari kelompok siswa dengan task commitment sedang, paling banyak siswa dengan kemampuan kognitif matematika tinggi $(17,4 \%)$ dibandingkan dengan siswa dengan kemampuan kognitif matematika sedang $(11,4 \%)$ dan rendah $(12,1 \%)$. Sehingga dapat dikatakan, kelompok siswa dengan task commitment sedang memiliki kemampuan kognitif matematika tinggi.

Berdasarkan uraian yang telah disampaikan, maka dapat disimpulkan bahwa terdapat hubungan atau asosiasi yang cukup kuat antara kemampuan kognitif matematika dengan task commitment siswa Kelas Khusus Olahraga (KKO) SMA negeri se-DIY. Semakin rendah task commitment siswa, maka semakin rendah pula kemampuan kognitif matematika siswa. Selanjutnya task commitment siswa tinggi, maka kemampuan kognitif matematika siswa sedang dan task commitment siswa sedang, maka kemampuan kognitif matematika siswa tinggi.

\section{SIMPULAN}

Hasil penelitian ini menunjukkan kemampuan kognitif matematika siswa KKO SMA negeri seDIY dalam kategori sedang dengan nilai rata-rata 40,62 dari nilai tertinggi ideal 100. Task commitment siswa KKO SMA negeri se-DIY dalam kategori sedang dengan nilai rata-rata 95,63 dari nilai tertinggi ideal 150, dan terdapat hubungan yang cukup kuat antara kemampuan kognitif matematika dan task commitment siswa KKO SMA negeri se-DIY. Hal ini dibuktikan dari nilai koefisien kontingensi $C_{s}=0,328$ yang berada pada interval 0,30-0,59 dan nilai signifikansi sebesar 0,05.

Berdasarkan hasil penelitian dan simpulan, terdapat beberapa saran yang dapat disampaikan. Saran bagi guru, agar lebih memperhatikan task commitment dan mengubah persepsi tentang siswa KKO, serta membiasakan siswa KKO untuk mengerjakan soal-soal penerapan dan penalaran untuk meningkatkan kemampuan kognitif matematika. Bagi pemerintah, agar dapat menjadikan hasil penelitian sebagai bahan pertimbangan dan referensi untuk melakukan perbaikan kurikulum dan pengayaan bahan ajar bagi siswa KKO, meningkatkan mutu pendidikan dalam mengembangkan potensi siswa berbakat khusus di DIY dan di seluruh Indonesia. Bagi peneliti selanjutnya, agar dapat meneliti dengan menemukan solusi untuk meningkatkan task commitment dan kemampuan kognitif matematika siswa KKO, menemukan model, metode maupun media pembelajaran yang baik dan cocok untuk siswa KKO.

\section{DAFTAR PUSTAKA}

Anderson, L. W., Krathwohl, D. R., Airasian, P. W., Cruikshank, K. A., Meyer, R. E., Pintrich, P. R., ... Wittrock, M. C. (2001). A taxonomy for learning, teaching, and assessing : a revision of Bloom's taxonomy of educational objectives. New York: Longman.

Asmara, A. S., Waluya, S. B., \& Rochmad, R. (2017). Analisis kemampuan literasi matematika siswa kelas X berdasarkan kemampuan matematika. Scholaria: Jurnal Pendidikan Dan Kebudayaan, 7(2), 135-142. https://doi.org/10.24246/j.scholaria.2017.v7.i2.p135-142

Bahar, A. (2013). The influence of cognitive abilities on mathematical problem solving performance. The University of Arizona.

Barmoyo, Q. N., \& Wasis, W. (2014). Analisis soal-soal dalam BSE (Buku Sekolah Elektronik), UN (Ujian Nasional) dan TIMSS (Trends in International Mathematics and Science Study) ditinjau dari domain kognitif dan indikator keterampilan berpikir kritis. Inovasi Pendidikan Fisika (Vol. 3). Retrieved from https://jurnalmahasiswa.unesa.ac.id/index.php/inovasi-pendidikanfisika/article/view/7162 
Bietenbeck, J. (2014). Teaching practices and cognitive skills. Labour Economics, 30, 143-153. https://doi.org/https://doi.org/10.1016/j.labeco.2014.03.002

Blaikie, N. (2003). Analyzing quantitative data: From description to explanation. London, United Kingdom: Sage.

Ceylan, E. (2013). Investigating science content and cognitive domain scores with regard to low-and high-performing schools in Turkey. Journal of Education and Future, (4), 35.

Cohen, L., Manion, L., \& Morrison, K. R. B. (2002). Research methods in education. New York, N.Y.: Routledge.

Ebel, R. L., \& Frisbie, D. A. (1991). Essentials of educational measurement. New Delhie: Prentice Hall.

Firmanto, A. (2013). Kecerdasan, kreatifitas, task commitment dan jenis kelamin sebagai prediktor prestasi hasil belajar siswa. Jurnal Sains Dan Praktik Psikologi, 1(1). Retrieved from http://ejournal.umm.ac.id/index.php/jspp/article/view/1342

Hakim, A. R. (2017). Prestasi belajar matematika ditinjau dari sikap dan komitmen diri peserta didik pada pelajaran matematika. JKPM (Jurnal Kajian Pendidikan Matematika), 2(1), 24-36. https://doi.org/10.30998/jkpm.v2i1.1892

Hanif, A. S. (2011). Evaluasi terhadap sekolah khusus olahragawan SMP/SMA Ragunan Jakarta. Jurnal Cakrawala Pendidikan, XXX(2). https://doi.org/10.21831/cp.v0i2.4231

Huda, N. (2012). Analisis kemampuan berdasarkan ranah kognitif siswa akselerasi menyelesaikan soal materi lingkaran di SMP N 7 Kota Jambi. Sainmatika: Jurnal Sains Dan Matematika Universitas Jambi, 5(1).

Kartikasari, M., Kusmayadi, T. A., \& Usodo, B. (2016). Kreativitas guru SMA dalam menyusun soal ranah kognitif ditinjau dari pengalaman kerja. Prosiding Seminar Nasional Matematika Dan Pendidikan Matematika, $O(0)$. Retrieved from http://jurnal.fkip.uns.ac.id/index.php/snmpm/article/view/10852

Kerr, B. (2009). Encyclopedia of giftedness, creativity, and talent. Thousand Oaks, California: SAGE Publications, Inc. https://doi.org/10.4135/9781412971959

Kilpatrick, J., Swafford, J., \& Findell, B. (2001). Adding it up: Helping children learn mathematics. Washington D.C.: National Academies Press.

Kiran, C. N., \& Murthy, C. G. V. (2016). Giftedness among school children: A review. The International Journal of Indian Psychology, 3(3), 119-129.

Latham, G. P., Seijts, G., \& Crim, D. (2008). The effects of learning goal difficulty level and cognitive ability on performance. Canadian Journal of Behavioural Science/Revue Canadienne Des Sciences Du Comportement, 40(4), 220. https://doi.org/10.1037/a0013114

Lestari, N. T. (2016). Analisis kemampuan kognitif, menalar dan sikap siswa smp pada materi ekosistem dikaitkan dengan gender. In Prosiding SNPBS (Seminar Nasional Pendidikan Biologi dan Saintek) Ke-1. Universitas Muhammadiyah Surakarta. Retrieved from https://publikasiilmiah.ums.ac.id/handle/11617/8019?show=full

Mahmudi, A. (2016). Memberdayakan pembelajaran matematika untuk mengembangkan kompetensi masa depan. In Seminar Nasional Matematika dan Pendidikan Matematika UNY 2016 (pp. 1-6). Yogyakarta: Universitas Negeri Yogyakarta.

McCaul, K. D., Hinsz, V. B., \& McCaul, H. S. (1987). The effects of commitment to performance goals on effort. Journal of Applied Social Psychology, 17(5), 437-452. https://doi.org/10.1111/j.1559-1816.1987.tb00323.x

McGee, M. (2017). Academics and the student athlete: a mixed methods study on the role of athletics in the high school educational setting. Rowan University. Retrieved from https://rdw.rowan.edu/etd/2367/

Mufidah, D., Suharto, S., \& Setiawan, T. B. (2018). Pengaruh kemampuan intelegensi dan task commitment terhadap hasil belajar matematika siswa Kelas XII MAN 1 Jember. Jurnal Edukasi, 5(1), 49. https://doi.org/10.19184/jukasi.v5i1.8375 
Munandar, U. (1992). Mengembangkan bakat dan kreativitas anak sekolah. Jakarta: Gramedia.

Munandar, U. (2014). Pengembangan kreativitas anak berbakat. Jakarta: Rineka Cipta.

Najamuddin, N., Idris, R., \& Afiif, A. (2015). Pengaruh kecerdasan interpersonal dan taks commiment terhadap hasil belajar matematika siswa kelas VIII MTS Negeri Balang-Balang Kabupaten Gowa. MaPan : Jurnal Matematika Dan Pembelajaran, 3(2), 163-176. https://doi.org/10.24252/MAPAN.2015V3N2A3

Park, M.-J., \& Lee, Y.-S. (2011). The relationship between learning motivation and task commitment of science-gifted. Journal of Gifted/Talented Education, 21(4), 961-977. https://doi.org/10.9722/jgte.2011.21.4.961

Phillipson, S., \& Phillipson, S. N. (2012). Children's cognitive ability and their academic achievement: The mediation effects of parental expectations. Asia Pacific Education Review, 13(3), 495-508. https://doi.org/10.1007/s12564-011-9198-1

Pianyta, A. (2017). Pengaruh kedisiplinan dan task commitment terhadap prestasi belajar matematika. JKPM (Jurnal Kajian Pendidikan Matematika), 2(1), 80. https://doi.org/10.30998/jkpm.v2i1.1896

Riduwan, M. B. A. (2006). Belajar mudah penelitian untuk guru-karyawan dan peneliti pemula. Bandung: Alfabeta.

Santos, S., \& Barmby, P. (2010). Enrichment and engagement in mathematics. In Proceedings of the British Congress for Mathematics Education (pp. 199-206).

Sari, Y. P., Amilda, A., \& Syutaridho, S. (2017). Identifikasi kemampuan kognitif siswa dalam menyelesaikan soal-soal materi bangun ruang sisi datar. Jurnal Pendidikan Matematika RAFA, 3(2), 146-164. https://doi.org/10.19109/jpmrafa.v3i2.1738

Subotnik, R. F., Olszewski-Kubilius, P., \& Worrell, F. C. (2011). Rethinking giftedness and gifted education: A proposed direction forward based on psychological science. Psychological Science in the Public Interest, Supplement, 12(1), 3-54. https://doi.org/10.1177/1529100611418056

Sudjana, M. A. (2005). Metoda statistika. Bandung: Tarsito.

Taub, G. E., Floyd, R. G., Keith, T. Z., \& McGrew, K. S. (2008). Effects of general and broad cognitive abilities on mathematics achievement. School Psychology Quarterly, 23(2), 187-198. https://doi.org/10.1037/1045-3830.23.2.187

Tayibu, N. Q. (2016). Pengaruh intelegensi, task commitment dan self efficacy terhadap hasil belajar matematika siswa SMA. Journal of Educational Science and Technology (EST), 2(3), 132. https://doi.org/10.26858/est.v2i3.2104

Thompson, R. A. (2012). Nurturing future generations: Promoting resilience in children and adolescents through social, emotional and cognitive skills. New York, N.Y.: Routledge.

Turner, R. (2010). Identifying cognitive processes important to mathematics learning but often overlooked. Teaching Mathematics? Make It Count:What Research Tells Us About Effective Teaching and Learning Mathematics, 56-61.

Urhahne, D. (2011). Teachers' judgments of elementary students' ability, creativity and task commitment. Talent Development and Excellence, 3(2), 229-237.

Veloo, A., Ali, R. M., \& Krishnasamy, H. N. (2014). Affective determinants of additional mathematics achievement in Malaysian technical secondary schools. Procedia - Social and Behavioral Sciences, 112, 613-620. https://doi.org/https://doi.org/10.1016/j.sbspro.2014.01.1208

Widanarti, J. (2016). Persepsi guru terhadap siswa kelas khusus olahraga (KKO) dalam mengikuti pembelajaran di SMA Negeri 4 Yogyakarta tahun ajaran 2016/2017. Pendidikan Jasmani Kesehatan Dan Rekreasi, 1(5). Retrieved from http://journal.student.uny.ac.id/ojs/index.php/pjkr/article/view/4456 